\title{
Social Comparisons and Satisfaction with Work
}

\author{
Jessica Halliday Hardie ${ }^{1}$
}

July 18, 2016

\section{Working Draft: Please do not cite without author's permission.}

\begin{abstract}
Two social psychological theories, relative deprivation theory and multiple discrepancies theory, suggest that individuals' wellbeing depends, in part, on how they compare themselves to others or previously established standards. The current study uses 24 waves of data from the National Longitudinal Survey of Youth $1979(N=9,813)$ and employs random-and fixed-effects models to examine whether job satisfaction is a function of four social comparisons: 1) the gap between occupational aspirations in adolescence and attainment, 2) the gap between parents' occupational attainment and respondent's occupational attainment, 3) the gap between siblings' occupational attainment and respondent's occupational attainment, and 4) the gap between predicted occupational attainment and actual occupational attainment. Findings reveal job satisfaction is negatively associated with falling short of one's aspirations and falling short of one's predicted occupational attainment. Exceeding one's parents' attainment is associated with higher odds of job satisfaction. However, associations between relative deprivation (or relative gain) and job satisfaction fades with age; young people's satisfaction with their jobs may be swayed to a greater degree by social comparisons than older adults' satisfaction. These findings make a unique contribution to the relative deprivation and multiple discrepancies theories, our understanding of wellbeing in relation to work, and variation over the life course.
\end{abstract}

${ }^{1}$ Department of Sociology, Hunter College-CUNY, 695 Park Avenue, New York, New York 10065; email: jh1389@hunter.cuny.edu 
The American dream that we were all raised on is a simple but powerful one:

If you work hard and play by the rules, you should be given a chance to go as far as your God-given ability will take you.

-President William J. Clinton, Remarks to the Democratic Leadership Council, 1993

The American Dream is a powerful ideology in the American consciousness, expressed not only as a rhetorical point made by politicians, but also held by millions of Americans. In 2002, for example, slightly over $70 \%$ of respondents to the National Educational Longitudinal Study (NELS) aspired to a professional occupation (Goyette 2008). Indeed, occupational aspirations have risen steadily over time (Reynolds et al. 2006; Shu and Marini 2008). Research by the Pew Research Center finds that $66 \%$ of young women and $59 \%$ of young men say that career success is "one of the most important things" or "very important" in their lives (Patten and Parker 2012). Another study finds that $61 \%$ of adults say their children will be better off than them (Kohut 2014). Thus, through economic recessions and rising inequality, Americans cling to the idea that hard work and perseverance will pay off, that work is a central to one's life, and that children will exceed their parents' career success. Yet the implications of falling short are unclear.

According to relative deprivation theory (Merton and Rossi 1968; Runciman 1966), people judge themselves relationally, either in comparison to others around them or to a standard they set for themselves, and their wellbeing fluctuates in response to these comparisons. Some research supports this perspective, showing that falling short of occupational aspirations is associated with lower wellbeing (Carr 1997; Hardie 2014). However, these studies did not examine other forms of "falling short", such as attaining less than one's parents, siblings, or others with similar educational attainment. Both studies also used special populations (middle 
aged women and young adults, respectively). Thus, we do not know whether the association between falling short of one's goals and wellbeing simply reflects other comparisons at play (e.g. comparison to one's parents) or disappointment over not meeting one's goals. In addition, we do not know whether the negative effects of falling short—or the positive effects of meeting or exceeding one's standards - persists or dissipates over time, as individuals set new standards, nor whether the findings from prior studies will hold when examining a more diverse sample.

The current study is the first to examine the relationship between multiple measures of relative deprivation in the labor market and job satisfaction across the life course. This paper advances prior literature on social comparisons by using rich panel data, a nationally representative sample of adults extending across the life course, and four social comparison measures. I use the National Longitudinal Survey of 1979 to investigate the relationship between relative occupational prestige and job satisfaction. Job satisfaction is an ideal outcome for this study because it is the most plausible consequence of social comparisons of occupational success - a worker who falls short of his or her occupational goals is likely to first express dissatisfaction in the area of work before repercussions in other life domains. Furthermore, job satisfaction is correlated with a host of other wellbeing outcomes (Faragher, Cass, and Cooper 2005; Fischer and Sousa-Pouza 2008). I use 24 waves of survey data, spanning from age 15 to 53. I test four types of relative deprivation: 1) falling short of one's adolescent occupational aspirations, 2) falling short of parents' occupational attainment, 3) falling short of siblings' occupational attainment, and 4) falling short of predicted occupational attainment based on educational attainment. 


\section{THEORETICAL BACKGROUND}

According to relative deprivation theory (Merton and Rossi 1968; Runciman 1966), individuals' happiness depends upon their success relative to others' success. These comparisons may be made to a reference group, such as peers, co-workers, friends, or neighbors (e.g. Bernburg, Thorlindsson, and Sigfusdottir 2009; Yngwe et al. 2005). Alternatively, individuals may compare themselves to an idealized or hoped-for circumstance (Pisarik and Shoffner 2009). This is congruent with multiple discrepancies theory (Michalos 1985), which suggests that happiness and satisfaction are related to comparisons between what one wants and has, what one had in the past, and what others have. Taken together, relative deprivation theory and multiple discrepancies theory suggest that comparisons to key reference points provide a baseline against which individuals judge their success and, in turn, register their satisfaction or disappointment. In the following sections, I discuss evidence and arguments for these theories in relation to aspirations, parents, siblings, and educational attainment.

\section{Relative Deprivation and Aspirations}

Aspirations are potentially important standards for comparison because they represent benchmarks that individuals set for themselves. Indeed, sociological theory has long asserted the importance of a free and open society in which people dream big and accomplish what they set out to do, given the inclination and ability to work hard (Durkheim 1997 [1951]; Merton 1938). When opportunities for advancement are blocked, these theories suggested costs to wellbeing for both the individual and society. According to Durkheim, unrealized expectations create anomie among the middle class during periods of prosperity (1997 [1951]), while Merton contended that anomie and deviance arose when segments of society, such as the poor, are barred access to institutionalized means of accomplishing culturally defined goals (1938). 
Previous research, using mostly cross-sectional data with small samples, has shown support for a negative association between falling short of one's aspirations and wellbeing. For example, Michalos (1985) used a small, cross-sectional survey of college students to show that happiness and satisfaction are negatively correlated with the discrepancy between what an individual wants and what they have. Other research uses synthetic panel cohorts to show that periods in the life course when men and women attained expected levels of material goods and family life statuses are associated with an increase in happiness (Plagnol and Easterlin 2008). Though these studies used slightly different measures of expectations than utilized here, they demonstrate that a discrepancy between goals and outcomes might lead to lower levels of satisfaction and wellbeing.

A small number of studies have used prospective data to estimate the relationship between falling short of one's aspirations and wellbeing in adulthood. For example, Carr (1997) and Hardie (2014) both found a negative association between falling short of one's occupational aspirations and wellbeing in adulthood. The Carr (1997) study focused on women in the Wisconsin Longitudinal study and found that women in their 50s who had fallen short of the occupational goals they set in their 30s had lower levels of life purpose and higher levels of depression than those who had met their goals. The Hardie (2014) study used both the National Longitudinal Study of Youth 1979 and the National Educational Longitudinal Study to show that there was a positive association between falling short of one's adolescent occupational aspirations and depression in young adulthood, and a negative association between falling short of one's goals and job satisfaction, also measured in young adulthood. Lastly, Reynolds and Baird (2010) found no relationship between falling short of one's educational aspirations and wellbeing in adulthood. However, this may be because educational aspirations tend to be even 
loftier than occupational aspirations; many adolescents expect to obtain higher educational credentials than are necessary for their intended careers (Goyette 2008). Therefore, a greater proportion of the population will fall short of their educational goals than those falling short of their occupational goals. This may alleviate disappointment in response to unmet educational aspirations.

\section{Relative Deprivation and Parents}

Individuals may also compare themselves to family members, particularly those close to them, when evaluating their satisfaction with work. Mothers and fathers are expected to be particularly important sources of social comparison, because their occupations are determinants of the social class in which one was raised. If individuals obtain a job that is not as prestigious or remunerative as their parents, they may feel dissatisfied with their job. One study found, for example, that subjective wellbeing was a function of mobility, with those earning more than their parents reporting better subjective wellbeing and those earning less reporting lower subjective wellbeing (Dolan and Lordan 2013). Another study used data from the General Social Survey to show that downward mobility was negatively associated with self-reported happiness and health while upward mobility was positively associated with these outcomes (Nikolaev and Burns 2014). This research found that income mobility was particularly prominent in explaining the association between mobility and wellbeing. Finally, some studies have examined associations between class mobility and self-rated mobility and wellbeing (e.g. Clark and D'Angelo 2013; McBride 2001). Thus, prior research suggests that comparisons to one's parents' economic standing are associated with self-rated wellbeing. The current study builds upon this research by using a longitudinal survey of American young people, employing robust methods to estimate associations between changes in mobility and changes in job satisfaction. 


\section{Relative Deprivation and Siblings}

Siblings may also be a point of comparison. Relationships with one's siblings are an important part of childhood and adulthood (Connidis and Campbell 1995; Whiteman, McHale, and Soli 2011). These relationships can bring a great deal of comfort and support to individuals, but they can also be a source of rivalry (Sulloway 1996). For example, some research has suggested that perceived unequal treatment by parents toward sibling pairs may influence youth outcomes (Feinberg et al. 2000; Scholte et al. 2007). This suggests that siblings compare themselves to one another, at least in terms of treatment within the family. Less is known, however, regarding the influence of comparisons based on occupational attainment.

\section{Relative Deprivation and Educational Attainment}

Finally, workers may feel a sense of disappointment if they are overeducated for the job they hold. Overeducation is difficult to define, because the educational standards for jobs change over time (Chevalier 2003; Halaby 1994). Although some ascribe this shift to jobs' increasing complexity, others argue that the shifting goalposts are responses to increasing education in the population rather than the needs of the job. However, studies that estimate overeducation as acquiring more education than is typical for the job they hold have found that overeducated workers are less satisfied with their jobs (e.g. Fleming and Kler 2008; Tsang and Levin 1985). Using the logic of social comparison suggests a similar conclusion; that falling short of the occupational attainment of one's educational peers (those attaining the same level of education) will leader to lower levels of job satisfaction.

\section{Relative Success?}

Relative deprivation and multiple discrepancies theories are primarily concerned with the association between falling short of some standard and lower subjective wellbeing. However, it 
is important to consider the association between exceeding one's comparison point—whether aspirations, parents' and siblings' attainment, or predicted attainment—and wellbeing. On the one hand, the logic of these social psychological theories suggests that high attainment relative to family, aspirational, or educational standards would be associated with higher levels of satisfaction and wellbeing. On the other hand, early sociological theories posit that mobility, at least, may be associated with lower subjective wellbeing regardless of its direction (Sorokin 1959). According to this theoretical perspective, moving from one social class to another would negatively impact health because the mobile individual would have to adapt to new norms, values, and contexts. This may suggest that exceeding one's parents' attainment, at least, would not lead to higher levels of job satisfaction. This may be true of aspirations as well; adolescents' and young adults' aspirations signal the social class within which respondents may feel most comfortable. Exceeding these expectations may therefore place them in unfamiliar settings and may be associated with lower job satisfaction in the long run.

\section{DATA AND METHODS}

The National Longitudinal Survey of Youth, 1979 (NLSY) is an ongoing, longitudinal study of young people who were between the ages of 14 and 22 in 1979. Participants were interviewed annually until 1994 and every other year after that time. The initial sample size was 12,686 young men and women, inclusive of a core nationally representative sample $(\mathrm{N}=6,111)$; a supplemental sample of Hispanic or Latino, Black, and economically disadvantaged nonBlack/non-Hispanic youth $(\mathrm{N}=5,295)$; and a nationally representative sample of youth serving in the military $(\mathrm{N}=1,280)$. This data includes 2,149 family units in which two or more siblings were sampled. 
The current study uses data from all available participants between the baseline survey 1979, when they were ages 14 to 21 , and 2010, when they were ages 45 to 53 . I include the baseline survey to obtain necessary control variable information, and cap the endpoint in 2010 so as to avoid any retirees or those nearing retirement. The NLSY79 asked respondents about their jobs and satisfaction as long as they had been employed at some point in the prior year, so temporary unemployment did not interfere with sample inclusion. I drop person-years in which respondents were under age 20 , enrolled in school, or in the active duty military. Attrition varied at each wave, but generally increased over time. In 2010, 7,565 original sample members participated in the study, comprising $60 \%$ of the original sample. The official retention rate was higher, at $76 \%$. This is because study staff intentionally dropped most of the military sample in 1985 and a small number of original sample members became ineligible for reinterview. Males, first generation immigrants, and those raised in single or stepfamily households were more likely to attrit. Whites were also more likely to attrit, but this was due to intentional dropping of subsamples. I used multiple imputation to fill in missing data in the baseline year. However, given the large number of survey years included in this analysis (32), multicollinearity interfered with imputation for the longitudinal data. For some variables (e.g., presence of a child in the home, marital status), no longitudinal data was imputed. In some cases, like educational attainment, I was able to fill in missing data from surveys before and after the year in question. The analytic sample size comprises 9,813 respondents and 107,235 person-years. ${ }^{1}$

\section{Measures}

\section{Outcome variable}

\footnotetext{
${ }^{1}$ In order to compare findings across random effects models, cases with missing data from any dependent variables were dropped. Analyses using all available information without regard to missing data on another dependent variable produced consistent results.

${ }^{2}$ Although respondents were asked about age 35 specifically, I use this as a measure of career occupational aspirations. Adolescents and young adults are unlikely to make distinctions between jobs achievable in their mid-30s
} 
Job satisfaction was measured on a four-point scale from "dislike it very much" (1) to "like it very much" (4). Those temporarily unemployed or not employed were asked to rate their satisfaction with their most recent job. The vast majority of respondents indicated they either liked their jobs somewhat or very much in every wave $(90.2 \%)$. Therefore, I recoded this variable into a dichotomous indicator of $1=$ likes job very much $(44.91 \%)$ and $0=$ all other responses. I refer to this as "job satisfaction" for brevity in the results.

\section{Independent variables}

The four key explanatory variables in this study are: 1) the gap between occupational aspirations and occupational attainment, 2) the gap between parental occupational attainment and respondent's occupational attainment, 3) the gap between sibling occupational attainment and respondent's occupational attainment, and 4) the gap between predicted occupational attainment based on educational attainment and respondent's actual occupational attainment. These measures vary over time, as respondents change jobs (and in the case of siblings, their comparison group changes jobs as well). Each measure is described below.

Unmet aspirations: For each outcome year, a measure of unmet aspirations was constructed from two survey items: occupational aspirations at the first survey and occupational attainment in the outcome year. To obtain occupational aspirations, respondents were asked in 1979 what they would like to be doing at age 35: working, raising a family, or something else. They were asked their occupational aspiration ("What kind of work would you like to be doing at age 35 ?") $)^{2}$ with wording varying according to their general plans (e.g., those who indicated they wished to raise a family were asked, if they were to work, what kind of job they would like to

\footnotetext{
${ }^{2}$ Although respondents were asked about age 35 specifically, I use this as a measure of career occupational aspirations. Adolescents and young adults are unlikely to make distinctions between jobs achievable in their mid-30s to those achievable in their mid-40s. Furthermore, in the 1970s, job tenure was relatively long once workers reached their 30s (Hall 1982), making aspirations for age 35 a good representation of the kind of job these young people thought they would hold through adulthood.
} 
hold). This strategy ensured that even respondents who did not plan to work reported an aspiration. Occupational attainment was reported in each survey year for respondents who were working or had worked at any point in the prior year. Temporarily unemployed respondents reported occupational information for their most recent job. Occupational aspirations and attainment were converted from 1970 census codes into the Stevens and Featherman (1981) socioeconomic index (SEI) of occupational status. This measure was derived by regressing occupational prestige on the percentage of occupational incumbents who earned incomes of $\$ 10,000$ or more and the percentage who had attended college for at least one year. ${ }^{3}$

Respondents' occupational aspiration SEI score was subtracted from their occupational attainment score, to obtain a linear measure of the gap between goals and outcome, ranging from -65 to 76 , with higher (positive) numbers indicating exceeding one's aspirations and more negative numbers indicating falling short. As a final step, this scale was converted into four categories: 1) falling short of the prestige of one's occupational aspiration by at least 5 points, 2) coming within 5 points of one's occupational aspiration prestige, 3 ) exceeding the prestige of one's occupational aspiration by at least 5 points, and 4) did not know aspiration in $1979^{4}$. For this explanatory variable and the others described below, various cut-off points were considered, including setting matching to those who attained the exact prestige they aspired to, those who fell short or exceeded by 10 points, and those who fell short or exceeded by 15 points. The 5-point difference was chosen because it was a substantively meaningful cut-off for differences in occupational attainment. For example, there is a 5-point difference between architects and

\footnotetext{
${ }^{3}$ Occupational rankings are, by necessity, blunt tools. They do not incorporate a range of characteristics that may be important to a worker, such as autonomy, cleanliness, health benefits, and job security. However, in comparing one's attainment to earlier aspirations, to parents' and siblings' occupations, and to one's predicted occupation, it provides a useful and methodologically concise heuristic representing relative attainment.

${ }^{4}$ In total, 637 respondents reported that they did not know what they wanted to being doing at age 35 . This category was not included in fixed effects models because it did not change over time for any respondents.
} 
computer systems analysts, and between therapists and clinical laboratory technicians. By comparison, there is a 10-point gap between registered nurses and therapy assistants. Matching exactly was not useful for all outcomes except the aspirations-attainment comparison, because matching one's parents, siblings, or predicted occupational attainment was so rare.

Comparison to parental occupational attainment: The gap between parents' occupational attainment and respondents' occupational attainment was measured in a similar manner to unmet occupational aspirations. In this case, each parent's occupational attainment from when the respondent was age 14 was converted into its Stevens and Featherman SEI equivalent. Next, I constructed a measure of highest parental attainment by selecting the highest of the two (or in some cases one) scores. Next, the parental SEI score was subtracted from the respondent's SEI score to produce a gap measure similar to that described above. Scores were then recoded into three categories: 1) falling more than 5 points below parents on the SEI scale, 2) falling within 5 points of parents, and 3) exceeding parent's attainment by more than 5 points.

Comparison to siblings' occupational attainment: Families in which two or more siblings were sampled ( $\mathrm{N}=2,149$ family units) were used for sibling analyses. Respondents with siblings who were also interviewed were significantly more likely to be male and Black, and less likely to be non-Black, non-Hispanic. They were much more likely to live with parents who had dropped out of high school and less likely to live with parents whose highest degree with a high school diploma, whereas parental educational attainment at the high end was equivalent for those with and without siblings in the data. Those with siblings in the data had lower AFQT scores, on average. In households with more than two siblings included in the sample, a random sibling is chosen as a comparison point. The sibling comparison measure is constructed similarly to parental comparisons. The gap between respondent's occupational SEI score and their sibling's 
SEI score was computed, and then simplified into a categorical measure: 1) falling more than 5 points below sibling on the SEI scale, 2) falling within 5 points of sibling, and 3) exceeding sibling's attainment by more than 5 points.

Comparison to predicted occupational attainment: Finally, I created a measure of how far the respondent fell short of or exceeded his or her predicted occupational SEI score when judged against his or her peers. To do this, I first generated a median SEI score for each educational, age, and gender grouping. Educational degree was divided into seven categories: less than a high school degree, GED, high school degree, technical degree or certificate, some college but no degree, Associate's degree, Bachelor's degree, and graduate/professional degree. Age was divided into six categories: 1) 20-25, 2) 26-30, 3) 31-35, 4) 36-40, 5) 41-45, and 6) 4653. Including gender, therefore, there were 84 groups for which predicted SEI score was generated. For the presented results, I use the median SEI score for each group as the "predicted" occupational SEI score. Alternative analyses using group means produced the equivalent multivariate results, but a different distribution of respondents in each category. Once obtained, the respondent's predicted SEI score was subtracted from their occupational SEI score. Finally, this measure was divided into categories similar to those created for comparison to parents: 1) fell below predicted attainment by more than 5 points, 2) came within 5 points of predicted attainment, and 3) exceeded predicted attainment by more than 5 points.

\section{Control variables}

As described below, I use both random and fixed effects models to estimate job satisfaction. Therefore, time invariant control variables are only included in random effects models, whereas time varying factors are included in both sets of analyses. Control variables obtained from the baseline survey adjust for early life course and demographic factors. Sex was 
controlled for with a dummy variable indicating the respondent was male (1) or female (0).

Race/ethnicity is measured using dichotomous indicators of Black or Latino, with non-Black, non-Latino as the reference category. I include an indicator of whether the respondent was living with two biological or adoptive parents at age 14 and a variable indicating the number of siblings in the home. Highest parental education is also included, indicating whether the highest attaining parent: 1) no high school degree, 2) high school degree (reference), 3) some college, 4) BA/BS degree, and 5) graduate or professional schooling. Immigrant status indicates whether respondents are first or second generation immigrants compared to non-immigrants.

I also included variables measuring respondents' likelihood to have a "good job" in a particular year. The Armed Forces Qualifying Test (AFQT) provides an indicator of ability, as measured in the baseline survey. Years of schooling completed are also controlled for. For each year, occupational attainment is controlled using an indicator of the respondent's current or most recent job's Stevens-Featherman SEI score. ${ }^{5}$ Hourly wage (top-coded at \$200 dollars an hour) and hours worked in the survey week or most recent workweek are also controlled for. Marital status and number of children indicate current family status. Current employment status is categorized as employed (reference), unemployed, or out of the labor force. Lastly, age is controlled for.

\section{Analytic Strategy}

Models of job satisfaction are estimated using two approaches: random and fixed effects.

First, I estimate random effects logistic regression models with both time varying and stable

\footnotetext{
${ }^{5}$ Occupational aspirations are not controlled for, because including aspirations, attainment, and an indicator of the match between these two factors would result in an overspecified model. That is, controlling for attainment with aspirations controlled is akin to controlling for attainment with a measure of the gap between the two measures, such that including all three measures could make it difficult to isolate the true association between a gap in aspirationsoutcomes and depression and job satisfaction. In addition, it would not allow for retaining those who did not have an aspiration in the first wave.
} 
covariates. Because random effects models include error terms at both the individual and group level, they allow estimation of both time varying and time invariant characteristics in predicting job satisfaction. In addition, this modeling strategy allows me to include important populations, such as those who did not know their occupational aspirations at wave 1, whereas this group is dropped in the fixed effects models. This also allows me to estimate a final model including all predictors. The fixed effects regression models use different samples because of the groups dropped (e.g., those who did not have interviewed siblings), meaning any joint model including all key independent variables would necessarily rely on a much-reduced sample. However, random effects models make a stringent assumption that the error is uncorrelated with any of the independent variables. Therefore, I also used fixed effects logistic regression models, which examine within-person change, thus accounting for time-stable characteristics.

For both fixed and random effects models, I estimated five models: the first model estimates job satisfaction as a function of the gap between early aspirations and later attainment. The second examines the association between this dependent variable and the gap between parental and child attainment. The third model uses the gap between siblings as a predictor. Finally, the fourth model examines the gap between predicted and actual attainment. I also estimate a fifth model in analyses using random effects that includes all social comparison predictors. I am able to do this using random effects modeling because I include a categorical indicator of "don't know" for the aspirations-attainment gap and an indicator of "no sibling" for the sibling analyses. Thus, my sample size does not change when including all four comparisons in one model. This allows me to examine the independent association of each social comparison and job satisfaction, holding other social comparisons constant. I cannot use the same approach with a fixed effects regression, however, because the "don't know" and "no sibling" categories 
are time invariant. Thus, a final model including all predictors would drop a large number of cases in comparison to the first four models, making it impossible to compare results. As described below, I use supplementary analyses to explore this issue.

In supplemental analyses, I ran several alternative models to test the robustness of my results. These included: 1) re-estimating the fixed effects models with only cases who stated an aspiration in 1979 and had a sibling in the data in order to compare a full model with all social comparison predictors to models with only one type of social comparison at a time; 2) dropping respondents not currently working; and 3) testing the interaction effect of age on the independent variables of interest.

\section{RESULTS}

Table 1 displays descriptive statistics. About half of all respondents fall short of their adolescent aspirations in adulthood, $15.99 \%$ come close to matching their aspirations, and $26.75 \%$ exceed them. A small percentage $(6.37 \%)$ of the population did not know their aspiration in 1979. Respondents' occupational status relative to their parents' occupations were almost evenly divided, with $31.90 \%$ falling short, $33.26 \%$ matching, and $34.85 \%$ exceeding. However, these descriptive statistics were based on person-years, and therefore underrepresent lifetime achievement. Supplemental analyses with respondents over age 40 show that $43 \%$ of respondents have exceeded the attainment of their parents. Almost $60 \%$ of the sample did not have siblings in the data, and among those that did, they were split between those who fell short, matched, and exceeded their comparison sibling's occupational attainment. Looking at predicted attainment based on educational qualifications, age, and gender, $21.40 \%$ of respondents fell short, $45.24 \%$ fell close to the expected occupation, and $33.36 \%$ exceeded. On average, respondents reported an occupational SEI score of 33.25 (similar to typists and carpenters). 


\section{TABLE 1 HERE}

Table 2 presents result from the random effects models estimating the association between social comparisons and job satisfaction. In Model 1, I find that falling short of one's aspired occupation $(O R=0.90, p<.001)$ is associated with lower log-odds of job satisfaction than attaining one's desired occupation. Not having an occupational aspiration is also associated with lower log-odds of job satisfaction in adulthood $(O R=0.82, p<.01)$. Model 2 finds that exceeding one's parents' occupational attainment is associated with higher log-odds of job satisfaction $(O R=1.11, p<.001)$. Model 3 shows no association between either exceeding or falling short of one's sibling's attainment and job satisfaction. Finally, Model 4 shows that attaining less than predicted based on one's gender, age, and educational attainment is associated with a lower log-odds of expressing that one is "very satisfied" with his or her job $(O R=0.89, p$ $<.001)$, whereas exceeding this predicted attainment is associated with higher log-odds of being satisfied $(O R=1.08, p<.05)$. Finally, all of these associations remain consistent when controlling for all three types of social comparison in Model 5.

\section{TABLE 2 HERE}

Several control variables are also important predictors of being very satisfied with one's job. Men, Black respondents, and first generation immigrants have lower log-odds of this outcome compared to women, non-Black and non-Hispanic respondents, and non-immigrants. Having a higher achievement score in adolescence is negatively associated with job satisfaction, whereas age is positively associated with this outcome. Higher occupational and educational attainments are both positively associated with the log-odds of being very satisfied with one's job, as are the job's hourly rate of pay and work hours. Having a child is associated with higher log-odds of reporting satisfaction with work. Those who are currently working report being more 
highly satisfied with their jobs than those who are unemployed. Finally, age is positively associated with job satisfaction.

Table 3 presents the results from the fixed effects regressions. Only time varying factors are included in these models, because the fixed effects model accounts for all time invariant characteristics. Results from these models, however, are similar to findings from the random effects models. Falling short of one's occupational aspirations are associated with lower log-odds of being very satisfied with one's job compared to matching one's goals $(O R=0.94, p<.05)$. Exceeding one's parents' occupational attainment is associated with an increase in the log-odds of a respondent saying they are very satisfied with their job $(O R=1.10, p<.001)$, and moving to a job with a lower than predicted SEI is associated with a lower log-odds of being very satisfied with one's job $(O R=0.92, p<.001)$.

\section{TABLE 3 HERE}

\section{Supplemental Analyses}

I conducted three alternative models using different measures of social comparisons and different subsets of the data. First, I re-estimated all models using only person-years in which respondents were currently working. All findings using this subset of person-years were consistent with the results in the full models. Second, I re-ran each fixed effects model and a final joint model including only respondents who had a sibling comparison and had stated an occupational aspiration in the first wave. Findings were consistent with the tables presented here except in the case of aspirations-attainment match. In the limited case models, falling short of one's aspirations was not associated with job satisfaction. This finding should be interpreted with caution, however, because it relies on a much smaller sample of those who had siblings in the data $(\mathrm{N}=4,136)$. 
Finally, I tested whether responses to each of the social comparisons varied by economic context. As noted above, Durkheim's theory of anomie predicts that anomie would be heightened during periods of relative prosperity (1997 [1951]), while Merton contended that anomie is higher when individuals are barred access to institutionalized means of accomplishing culturally defined goals (1938). To test both of these theories, I interacted each of the social comparison indicators with a dummy variable indicating whether the economy was in a period of expansion (1) rather than recession (0). To do this, I used the National Bureau of Economic Research's business cycle dating charts (see http://www.nber.org/cycles.html) ${ }^{6}$ to obtain the dates of each period of expansion and recession from 1979 to 2009, and matched these days to the month and year each respondent was interviewed for each wave. ${ }^{7}$ If findings indicate that social comparisons have a stronger impact on job satisfaction during periods of expansion, this would support Durkheim's contention that frustrated goals are more consequential during periods of relative prosperity. However, if findings indicate that social comparisons have a stronger impact on job satisfaction during recessions, this would support Merton's theory that anomie rises when goals are blocked by outside circumstances (e.g., too few jobs and negative economic growth). Findings tend to support Merton's theory; falling short of one's occupational aspirations have a larger negative impact on job satisfaction during periods of recession. Random effects models, but not fixed effects models, also show that falling short of parents is more negatively associated with job satisfaction during recessions, and exceeding one's predicted occupational attainment is more strongly predictive of high job satisfaction during recessions.

\footnotetext{
${ }^{6}$ The NBER's business cycle dating is the standard source for identifying recessions; a committee of business cycle experts make determinations based on a range of economic data, including GDI, GDP, and unemployment.

${ }^{7}$ For example, a respondent who answered the 1991 survey in February 1991 would be coded as responding during a recession, whereas someone who completed the survey in May 1991 would be coded as responding during an economic expansion. Periods of expansion began the month after the "trough" month and ended during the "peak" month. Recessions began the month after the "peak" month and ended during the "trough" month.
} 


\section{Discussion}

Two social-psychological theories, relative deprivation theory and multiple discrepancies theory (Merton and Rossi 1968; Michalos 1985; Runciman 1966), suggest that individual wellbeing is a function of social comparisons. That is, wellbeing is not solely determined by an absolute benchmark or standard definition of the "good life." Instead, we compare ourselves to others around us, and our happiness and wellbeing depend, in part, on how we measure up. In this study, I examined four social comparisons that people may make when judging their contentment or satisfaction: the gap between one's adolescent occupational aspirations and later attainment; the gap between one's parents' occupational attainment and one's own; the gap between a close sibling's occupational attainment and one's own; and the gap between one's "predicted" occupational attainment based on those of similar educational, age, and gender profiles and one's actual occupational attainment.

Findings using four sources of social comparison and two methodological approaches show the importance of relative levels of success for wellbeing. Respondents reported lower job satisfaction when not meeting their earlier aspirations and when falling short of those in the same age category and gender who attained a similar level of education. Falling short of parents' attainment was not associated with job satisfaction, but exceeding their attainment was associated with higher odds of reporting job satisfaction. There was also a positive association between exceeding one's predicted occupational attainment and job satisfaction in the random effects models, but not in the fixed effects models. There were no statistically significant associations between attainment relative to siblings and job satisfaction. Taken together, these findings suggest that people judge themselves — and their jobs - relative to comparisons they make to other people and prior standards. In particular, expectations play an important role in 
how individuals may judge themselves. Occupational aspirations are an explicit measure of what young people hope their lives will be like in the future. People may also expect to work in jobs at least as prestigious as those who are similar to themselves in terms of educational attainment, age, and gender. In both cases, those who fell short were less likely to express high levels of satisfaction with their jobs.

Interestingly, falling short of one's parents' attainment was not associated with lower job satisfaction. This might be because those who fall short anticipated this outcome earlier in life and were not disappointed by their attainment. Alternatively, if upward mobility is considered standard in the United States, either falling short or attaining the same level of occupational attainment as one's parents may both be seen as a disappointing outcome in comparison to exceeding one's parents' attainment. Lastly, the gap between sibling's attainment and respondent's attainment was unrelated to job satisfaction. This may be because there are few tropes regarding how one measures up to one's siblings. American cultural scripts place primacy on following one's dreams, pursuing aspirations, and becoming upwardly mobile (Cullen 2004, Hochschild 1996), thus making comparisons to parents and aspirations potentially more potent.

The current study contributes to the literature on relative deprivation, demonstrating how the gap between one's personal goals and attainment and the gap between others' attainment and one's own shape wellbeing in the labor market, over and above the impact of job characteristics such as wages, occupational socioeconomic index, and work hours. Furthermore, sensitivity analyses using alternative models lend credence to the stability of these findings. The study does have limitations, however. First, I would have preferred to use a more nuanced measure of job satisfaction that included questions about different aspects of the job. The dichotomous indicator is limited, and does not capture the full range of feelings one may have about a job. Second, 
sibling data was only available when respondents had siblings who were eligible for inclusion in the study - they had to be within the age range selected for the study in 1979. Therefore, I can only assess gaps between respondents and siblings included in the data, rather than the full range of siblings to which respondents might compare themselves.

Americans spend a substantial amount of time at work, and therefore their satisfaction with work is important to their overall happiness and wellbeing. Indeed, job satisfaction is correlated with a range of physical and mental health outcomes (Faragher, Cass, and Cooper 2005; Fischer and Sousa-Pouza 2008), as well as greater productivity in the workplace (Frey and Stutzer 2010). Findings from the current study suggest that comparisons to one's earlier goals, to parents, and to others of similar educational and demographic factors shape job satisfaction over the life course. Theoretically, this contributes to our understanding of human motivation and wellbeing, lending support to theories of relative deprivation and multiple discrepancies. As a practical concern, it suggests that individuals may benefit from better guidance as teens when setting their occupational aspirations. It also suggests the importance of highlighting the complexity of work benefits; jobs provide a wide range of characteristics (e.g., job hours, degree of flexibility, etc) that may appeal to some workers over others (Daw and Hardie 2012; Halaby 2003). Emphasizing this aspect of work may cushion individual responses to falling short of parents and predicted attainment along a single metric. 


\section{REFERENCES}

Alexander, Karl L. and Martha A. Cook. 1979. "The Motivational Relevance of Educational Plans: Questioning the Conventional Wisdom." Social Psychological Quarterly 42:202213.

Bernburg, Jón Gunnar. Thorolfur Thorlindsson, and Inga Dora Sigfusdottir. 2009. "Relative Deprivation and Adolescent Outcomes in Iceland: A Multilevel Test.” Social Forces 87: 1223-1250.

Carr, Deborah. 1997. “The Fulfillment of Career Dreams at Midlife: Does it Matter for Women's Mental Health.” Journal of Health and Social Behavior 38: 331-344.

Clark, Andrew E. and Emanuela D’Angelo. 2013. Upward Social Mobility, Well-Being and Political Preferences: Evidence from the BHPS. Centre for Economic Performance, LSE. Retrieved April 12, 2016 (https://ideas.repec.org/p/cep/cepdps/dp1252.html).

Connidis, Ingrid Arnet and Lori D. Campbell. 1995. "Closeness, Confiding, and Contact among Siblings in Middle and Late Adulthood." Journal of Family Issues 16:722-745

Chevalier, Arnaud. 2003. “Measuring Over-education.” Economica 70:509-531.

Cullen, Jim. 2004. The American Dream: A Short History of an Idea that Shaped a Nation. Oxford: Oxford University Press.

Daw, Jonathan and Jessica Halliday Hardie. 2012. “Compensating Differentials, Labor Market Segmentation, and Wage Inequality." Social Science Research 41: 1179-1197.

Dolan, Paul and Grace Lordan. 2013. "Moving Up and Sliding Down: An Empirical Assessment of the Effect of Social Mobility on Subjective Wellbeing." CEP Discussion Paper No 1190, Centre for Economic Performance, London School of Economics and Political Science. 
Durkheim, Emile. 1997 [1951]. Suicide: A Study in Sociology. New York: Free Press.

Faragher, E. B., M. Cass, and C. L. Cooper. 2005. "The Relationship between Job Satisfaction and Health: A Meta-analysis.” Occupational \& Environmental Medicine 62:105-112.

Feinberg, Mark E., Jenae M. Neiderhiser, Sam Simmens, David Reiss, and E. Mavis Hetherington. 2000. "Sibling Comparison of Differential Parental Treatment in Adolescence: Gender, Self-Esteem, and Emotionality as Mediators of the ParentingAdjustment Association." Child Development 71(6):1611-1628.

Fischer, Justina A. V. and Sousa-Pouza, Alfonso. 2008. "Does Job Satisfaction Improve the Health of Workers? New Evidence Using Panel Data and Objective Measures of Health.” SOEP Working Paper No. 76. Available at SSRN: http://ssrn.com/abstract=1098803

Fleming, Christopher M. and Parvinder Kler. 2008. "I'm Too Clever for this Job: a Bivariate Probit Analysis on Overeducation and Job Satisfaction in Australia." Applied Economics 40(9):1123-1138.

Frey, Bruno S., and Alois Stutzer. 2010. Happiness and Economics: How the Economy and Institutions Affect Human Well-being. Princeton, NJ: Princeton University Press.

Goyette, Kimberly A. 2008. "College for Some to College for All: Social Background, Occupational Expectations, and Educational Expectations over Time." Social Science Research 37: 461-484.

Halaby, Charles N. 1994. "Overeducation and Skill Mismatch.” Sociology of Education 67:4759.

Halaby, Charles N. 2003. "Where Job Values Come From: Family and Schooling Background, Cognitive Ability, and Gender.” American Sociological Review 68:251-78. 
Hall, Robert E. 1982. “The Importance of Lifetime Jobs in the U.S. Economy.” American Economic Review 72(4):716-724.

Hardie, Jessica Halliday. 2014. "The Consequences of Unrealized Occupational Goals in the Transition to Adulthood." Social Science Research 48: 196-211.

Hochschild, Jennifer L. 1996. Facing up to the American Dream: Race, Class, and the Soul of the Nation. Princeton, NJ: Princeton University Press.

Kohut, Andrew. "What will become of America's kids?" Pew Research Center, Washington, D.C. (May 12, 2014). http://www.pewresearch.org/fact-tank/2014/05/12/what-willbecome-of-americas-kids/, accessed August 30, 2015.

McBride, Michael. 2001. "Relative-Income Effects on Subjective Well-Being in the CrossSection.” Journal of Economic Behavior \& Organization 45(3):251-78.

Merton, Robert K. and Alice S. Rossi. 1968. "Contributions to the Theory of Reference Group Behavior." Pp. 279-440. Social Theory and Social Structure. Robert K. Merton, Ed. The Free Press.

Michalos, Alex C. 1985. "Multiple Discrepancies Theory (MDT)." Social Indicators Research 16: $347-413$.

Nikolaev, Boris and Ainslee Burns. 2014. "Intergenerational Mobility and Subjective Wellbeing-Evidence from the General Social Survey.” Journal of Behavioral and Experimental Economics 53:82-96.

Patten, Eileen and Kim Parker. "A Gender Reversal on Career Aspirations: Young Women Now Top Young Men in Valuing a High-Paying Career.” Pew Research Center, Washington, D.C. (April 19, 2012). http://www.pewsocialtrends.org/files/2012/04/Women-in-theWorkplace.pdf, accessed August 30, 2015. 
Pisarik, Christopher T. and Marie F. Shoffner. 2009. "The Relationship among Work Possible Selves, Socioeconomic Position, and the Psychological Well-Being of Individuals in Early Adulthood." Journal of Career Development 35: 306-325.

Plagnol, Anke C. and Richard A. Easterlin. 2008. "Aspirations, Attainments, and Satisfaction: Life Cycle Differences between American Women and Men.” Journal of Happiness Studies 9: 601-619.

Reynolds, John R. and Chardie L. Baird. 2010. "Is There a Downside to Shooting for the Stars? Unrealized Educational Expectations and Symptoms of Depression.” American Sociological Review 75: 151-172.

Reynolds, John, Michael Stewart, Ryan MacDonald, and Lacey Sischo. 2006. "Have Adolescents Become Too Ambitious? High School Seniors' Educational and Occupational Plans, 1976 to 2000.” Social Problems 53: 186-206.

Runciman, W. G. 1966. Relative Deprivation and Social Justice: A Study of Attitudes to Social Inequality in Twentieth Century England. London: Routledge and Kegan Paul.

Scholte, Ron H. J., Rutger C. M. E. Engels, Raymond A. T. de Kemp, Zeena Harakeh, and Geertjan Overbeek. 2007. "Differential Parental Treatment, Sibling Relationships and Delinquency in Adolescence." Journal of Youth and Adolescence 36(5): 661-671.

Shu, Xiaoling and Margaret Mooney Marini. 2008. "Coming of Age in Changing Times: Occupational Aspirations of American Youth, 1966-1980.” Research in Social Stratification and Mobility 26:29-55.

Sorokin, Pitirim A. 1959. Social and Cultural Mobility, $2^{\text {nd }}$ Ed. Glencoe, IL: Free Press. Stevens, Gillian and David L. Featherman. 1981. "A Revised Socioeconomic Index of Occupational Status." Social Science Research 10: 364-395. 
Sulloway, Frank J. 1996. Born to Rebel: Birth Order, Family Dynamics, and Creative Lives. New York: Pantheon Books.

Tsang, Mun C., and Henry M. Levin. 1985. "The Economics of Overeducation." Economics of Education Review 4(2): 93-104.

Whiteman, Shawn D., Susan M. McHale, and Anna Soli. 2011. “Theoretical Perspectives on Sibling Relationships.” Journal of Family Theory \& Review 3(2):124-139.

Yngwe, Monica Åberg, Johan Fritzell, Bo Burström, and Olle Lundberg. 2005. "Comparisons or Consumption? Distinguishing between Different Effects of Income on Health in Nordic Welfare States." Social Science \& Medicine 61: 627-635. 
Table 1: Descriptive Statistics $(\mathrm{N}=9,813)$

\begin{tabular}{|c|c|c|}
\hline & Mean $/ \%$ & Std. Dev \\
\hline Job satisfaction (very satisfied $=1$ ) & $44.54 \%$ & \\
\hline \multicolumn{3}{|l|}{ Aspirations-attainment match } \\
\hline Fall short & $50.89 \%$ & \\
\hline Match & $15.99 \%$ & \\
\hline Exceed & $26.75 \%$ & \\
\hline Don't know aspiration & $6.37 \%$ & \\
\hline \multicolumn{3}{|l|}{ Parent-respondent match } \\
\hline Fall short & $31.90 \%$ & \\
\hline Match & $33.26 \%$ & \\
\hline Exceed & $34.85 \%$ & \\
\hline \multicolumn{3}{|l|}{ Sibling-respondent match } \\
\hline Fall short & $13.34 \%$ & \\
\hline Match & $13.82 \%$ & \\
\hline Exceed & $13.19 \%$ & \\
\hline No sibling comparison & $59.65 \%$ & \\
\hline \multicolumn{3}{|c|}{ Predicted attainment-attainment match } \\
\hline Fall short & $21.40 \%$ & \\
\hline Match & $45.24 \%$ & \\
\hline Exceed & $33.36 \%$ & \\
\hline Male & $51.87 \%$ & \\
\hline \multicolumn{3}{|l|}{ Race/ethnicity } \\
\hline Hispanic & $17.52 \%$ & \\
\hline Black & $26.62 \%$ & \\
\hline Non-Hispanic, Non-Black & $55.86 \%$ & \\
\hline Two-parent family & $69.41 \%$ & \\
\hline Number of siblings & 3.81 & 2.59 \\
\hline \multicolumn{3}{|c|}{ Parents' highest educational attainment } \\
\hline Less than 12 years & $34.00 \%$ & \\
\hline 12 years of school & $40.11 \%$ & \\
\hline Some college & $11.49 \%$ & \\
\hline $\mathrm{BA} / \mathrm{BS}$ & $8.73 \%$ & \\
\hline Graduate/prof school & $5.67 \%$ & \\
\hline \multicolumn{3}{|l|}{ Immigrant status } \\
\hline First generation immigrant & $6.72 \%$ & \\
\hline Second generation immigrant & $6.49 \%$ & \\
\hline Non-immigrant & $86.78 \%$ & \\
\hline AFQT score & 41.97 & 28.60 \\
\hline R's years of schooling & 12.71 & 2.41 \\
\hline Occupational SEI Score & 33.25 & 17.17 \\
\hline Hourly wage & 17.72 & 12.28 \\
\hline Hours worked in survey week & 40.17 & 11.21 \\
\hline
\end{tabular}


Health limitation

Marital status

Single/never married

Married

Divorced/sep/widowed

Number of children

Employment

Working

Unemployed

Out of labor force
0.05

$33.77 \%$

$50.37 \%$

$15.86 \%$

1.24

1.31

$88.46 \%$

$4.85 \%$

$6.69 \%$

31.78 
Table 2: Random-effects models predicting satisfaction with job

\begin{tabular}{|c|c|c|c|c|c|}
\hline & $\begin{array}{l}\text { Aspirations- } \\
\text { Attainment }\end{array}$ & $\begin{array}{c}\text { Parent } \\
\text { comparison }\end{array}$ & $\begin{array}{c}\text { Sibling } \\
\text { comparison }\end{array}$ & $\begin{array}{l}\text { Expected- } \\
\text { Achieved }\end{array}$ & $\begin{array}{c}\text { All } \\
\text { comparisons }\end{array}$ \\
\hline \multicolumn{6}{|l|}{ Aspiration-attainment match } \\
\hline Short of aspiration & $\begin{array}{c}-0.104 * * * \\
(0.03)\end{array}$ & & & & $\begin{array}{c}-0.099 * * * \\
(0.03)\end{array}$ \\
\hline Exceeded aspirations & $\begin{array}{r}-0.039 \\
(0.04)\end{array}$ & & & & $\begin{array}{r}-0.049 \\
(0.04)\end{array}$ \\
\hline Don't know aspiration & $\begin{array}{c}-0.201 * * \\
(0.07)\end{array}$ & & & & $\begin{array}{c}-0.195 * * \\
(0.07)\end{array}$ \\
\hline \multicolumn{6}{|l|}{ Parent-respondent match } \\
\hline Short of parental attainment & & $\begin{array}{l}0.027 \\
(0.03)\end{array}$ & & & $\begin{array}{l}0.041 \\
(0.03)\end{array}$ \\
\hline Exceed parental attainment & & $\begin{array}{c}0.107 * * * \\
(0.03)\end{array}$ & & & $\begin{array}{c}0.093 * * \\
(0.03)\end{array}$ \\
\hline \multicolumn{6}{|l|}{ Sibling-respondent match } \\
\hline Short of sibling attainment & & & $\begin{array}{l}0.047 \\
(0.03)\end{array}$ & & $\begin{array}{l}0.046 \\
(0.03)\end{array}$ \\
\hline Exceed sibling attainment & & & $\begin{array}{l}0.015 \\
(0.04)\end{array}$ & & $\begin{array}{l}-0.005 \\
(0.04)\end{array}$ \\
\hline No sibling in data & & & $\begin{array}{l}0.011 \\
(0.04)\end{array}$ & & $\begin{array}{l}0.004 \\
(0.04)\end{array}$ \\
\hline \multicolumn{6}{|c|}{ Predicted attainment-attainment match } \\
\hline Short of predicted attainment & & & & $\begin{array}{c}-0.119 * * * \\
(0.03)\end{array}$ & $\begin{array}{c}-0.111^{* * *} \\
(0.03)\end{array}$ \\
\hline Exceed predicted attainment & & & & $\begin{array}{c}0.080^{*} \\
(0.03)\end{array}$ & $\begin{array}{c}0.066^{*} \\
(0.03)\end{array}$ \\
\hline Male & $\begin{array}{c}-0.177 * * * \\
(0.03)\end{array}$ & $\begin{array}{c}-0.167 * * * \\
(0.03)\end{array}$ & $\begin{array}{c}-0.173^{* * *} \\
(0.03)\end{array}$ & $\begin{array}{c}-0.190 * * * \\
(0.03)\end{array}$ & $\begin{array}{c}-0.190^{* * *} \\
(0.03)\end{array}$ \\
\hline \multicolumn{6}{|l|}{ Race/ethnicity } \\
\hline Hispanic & $\begin{array}{l}0.082 \\
(0.05)\end{array}$ & $\begin{array}{l}0.072 \\
(0.05)\end{array}$ & $\begin{array}{l}0.076 \\
(0.05)\end{array}$ & $\begin{array}{l}0.074 \\
(0.05)\end{array}$ & $\begin{array}{l}0.075 \\
(0.05)\end{array}$ \\
\hline Black & $\begin{array}{c}-0.402 * * * \\
(0.04)\end{array}$ & $\begin{array}{c}-0.417 * * * \\
(0.04)\end{array}$ & $\begin{array}{c}-0.412 * * * \\
(0.04)\end{array}$ & $\begin{array}{c}-0.410^{* * *} \\
(0.04)\end{array}$ & $\begin{array}{c}-0.405^{* * *} \\
(0.04)\end{array}$ \\
\hline Two-parent family & $\begin{array}{l}0.024 \\
(0.04)\end{array}$ & $\begin{array}{l}0.031 \\
(0.04)\end{array}$ & $\begin{array}{l}0.026 \\
(0.04)\end{array}$ & $\begin{array}{l}0.029 \\
(0.04)\end{array}$ & $\begin{array}{l}0.028 \\
(0.04)\end{array}$ \\
\hline Number of siblings & $\begin{array}{l}-0.005 \\
(0.01)\end{array}$ & $\begin{array}{l}-0.005 \\
(0.01)\end{array}$ & $\begin{array}{l}-0.005 \\
(0.01)\end{array}$ & $\begin{array}{l}-0.004 \\
(0.01)\end{array}$ & $\begin{array}{l}-0.004 \\
(0.01)\end{array}$ \\
\hline \multicolumn{6}{|l|}{ Highest parental education } \\
\hline Less than high school & $\begin{array}{l}-0.032 \\
(0.04)\end{array}$ & $\begin{array}{l}-0.032 \\
(0.04)\end{array}$ & $\begin{array}{l}-0.030 \\
(0.04)\end{array}$ & $\begin{array}{l}-0.028 \\
(0.04)\end{array}$ & $\begin{array}{l}-0.027 \\
(0.04)\end{array}$ \\
\hline Some college & $\begin{array}{l}0.030 \\
(0.05)\end{array}$ & $\begin{array}{l}0.035 \\
(0.05)\end{array}$ & $\begin{array}{l}0.028 \\
(0.05)\end{array}$ & $\begin{array}{l}0.030 \\
(0.05)\end{array}$ & $\begin{array}{l}0.035 \\
(0.05)\end{array}$ \\
\hline $\mathrm{BA} / \mathrm{BS}$ & $\begin{array}{l}0.047 \\
(0.06)\end{array}$ & $\begin{array}{l}0.057 \\
(0.06)\end{array}$ & $\begin{array}{l}0.035 \\
(0.06)\end{array}$ & $\begin{array}{l}0.042 \\
(0.06)\end{array}$ & $\begin{array}{l}0.059 \\
(0.06)\end{array}$ \\
\hline Grad/prof school & 0.087 & 0.115 & 0.077 & 0.091 & 0.115 \\
\hline
\end{tabular}




\begin{tabular}{|c|c|c|c|c|c|}
\hline & $(0.07)$ & $(0.07)$ & $(0.07)$ & $(0.07)$ & $(0.07)$ \\
\hline \multicolumn{6}{|l|}{ Immigrant status } \\
\hline First generation & $\begin{array}{c}-0.136^{*} \\
(0.07)\end{array}$ & $\begin{array}{c}-0.148^{*} \\
(0.07)\end{array}$ & $\begin{array}{c}-0.144^{*} \\
(0.07)\end{array}$ & $\begin{array}{c}-0.139^{*} \\
(0.07)\end{array}$ & $\begin{array}{c}-0.137 * \\
(0.07)\end{array}$ \\
\hline Second generation & $\begin{array}{c}-0.104 \\
(0.07)\end{array}$ & $\begin{array}{l}-0.111 \\
(0.07)\end{array}$ & $\begin{array}{l}-0.109 \\
(0.07)\end{array}$ & $\begin{array}{r}-0.110 \\
(0.07)\end{array}$ & $\begin{array}{c}-0.108 \\
(0.07)\end{array}$ \\
\hline AFQT score & $\begin{array}{c}-0.006^{* * *} \\
(0.00)\end{array}$ & $\begin{array}{c}-0.006^{* * *} \\
(0.00)\end{array}$ & $\begin{array}{c}-0.006^{* * *} \\
(0.00)\end{array}$ & $\begin{array}{c}-0.006^{* * *} \\
(0.00)\end{array}$ & $\begin{array}{c}-0.006^{* * * *} \\
(0.00)\end{array}$ \\
\hline Years of schooling & $\begin{array}{c}0.032 * * * \\
(0.01)\end{array}$ & $\begin{array}{c}0.031 * * * \\
(0.01)\end{array}$ & $\begin{array}{c}0.030^{* * *} \\
(0.01)\end{array}$ & $\begin{array}{c}0.047 * * * \\
(0.01)\end{array}$ & $\begin{array}{c}0.046^{* * * *} \\
(0.01)\end{array}$ \\
\hline Occupational SEI score & $\begin{array}{c}0.014 * * * \\
(0.00)\end{array}$ & $\begin{array}{c}0.014 * * * \\
(0.00)\end{array}$ & $\begin{array}{c}0.015^{* * *} \\
(0.00)\end{array}$ & $\begin{array}{c}0.011 * * * \\
(0.00)\end{array}$ & $\begin{array}{c}0.010^{* * *} \\
(0.00)\end{array}$ \\
\hline Hourly wages & $\begin{array}{c}0.011 * * * \\
(0.00)\end{array}$ & $\begin{array}{c}0.011 * * * \\
(0.00)\end{array}$ & $\begin{array}{c}0.011 * * * \\
(0.00)\end{array}$ & $\begin{array}{c}0.011 * * * \\
(0.00)\end{array}$ & $\begin{array}{c}0.011 * * * \\
(0.00)\end{array}$ \\
\hline Hours worked per week & $\begin{array}{c}0.006^{* * *} \\
(0.00)\end{array}$ & $\begin{array}{c}0.006 * * * \\
(0.00)\end{array}$ & $\begin{array}{c}0.006^{* * *} \\
(0.00)\end{array}$ & $\begin{array}{c}0.005^{* * *} \\
(0.00)\end{array}$ & $\begin{array}{c}0.005^{* * * *} \\
(0.00)\end{array}$ \\
\hline Health limitation & $\begin{array}{c}-0.133^{* *} \\
(0.04)\end{array}$ & $\begin{array}{c}-0.134 * * \\
(0.04)\end{array}$ & $\begin{array}{c}-0.133^{* *} \\
(0.04)\end{array}$ & $\begin{array}{c}-0.133 * * \\
(0.04)\end{array}$ & $\begin{array}{c}-0.134 * * \\
(0.04)\end{array}$ \\
\hline \multicolumn{6}{|l|}{ Marital status } \\
\hline Never married & $\begin{array}{l}-0.004 \\
(0.03)\end{array}$ & $\begin{array}{l}-0.005 \\
(0.03)\end{array}$ & $\begin{array}{l}-0.005 \\
(0.03)\end{array}$ & $\begin{array}{l}-0.007 \\
(0.03)\end{array}$ & $\begin{array}{l}-0.005 \\
(0.03)\end{array}$ \\
\hline Divorced/separated/widowed & $\begin{array}{l}0.016 \\
(0.03)\end{array}$ & $\begin{array}{l}0.016 \\
(0.03)\end{array}$ & $\begin{array}{l}0.016 \\
(0.03)\end{array}$ & $\begin{array}{l}0.014 \\
(0.03)\end{array}$ & $\begin{array}{l}0.016 \\
(0.03)\end{array}$ \\
\hline Has child & $\begin{array}{c}0.059 * * * \\
(0.01)\end{array}$ & $\begin{array}{c}0.059^{* * *} \\
(0.01)\end{array}$ & $\begin{array}{c}0.059 * * * \\
(0.01)\end{array}$ & $\begin{array}{c}0.060^{* * *} \\
(0.01)\end{array}$ & $\begin{array}{c}0.061 * * * \\
(0.01)\end{array}$ \\
\hline \multicolumn{6}{|l|}{ Employment status } \\
\hline Currently employed & $\begin{array}{c}0.178^{* * * *} \\
(0.04)\end{array}$ & $\begin{array}{c}0.179 * * * \\
(0.04)\end{array}$ & $\begin{array}{c}0.179 * * * \\
(0.04)\end{array}$ & $\begin{array}{c}0.180 * * * \\
(0.04)\end{array}$ & $\begin{array}{c}0.177^{* * *} \\
(0.04)\end{array}$ \\
\hline Out of the labor force & $\begin{array}{c}-0.027 \\
(0.05)\end{array}$ & $\begin{array}{c}-0.028 \\
(0.05)\end{array}$ & $\begin{array}{c}-0.028 \\
(0.05)\end{array}$ & $\begin{array}{l}-0.025 \\
(0.05)\end{array}$ & $\begin{array}{l}-0.027 \\
(0.05)\end{array}$ \\
\hline Age & $\begin{array}{c}0.007 * * * \\
(0.00)\end{array}$ & $\begin{array}{c}0.007 * * * \\
(0.00)\end{array}$ & $\begin{array}{c}0.007 * * * \\
(0.00)\end{array}$ & $\begin{array}{c}0.008 * * * \\
(0.00)\end{array}$ & $\begin{array}{c}0.008 * * * \\
(0.00)\end{array}$ \\
\hline Observations & 107,235 & 107,235 & 107,235 & 107,235 & 107,235 \\
\hline Number of ids & 9,813 & 9,813 & 9,813 & 9,813 & 9,813 \\
\hline
\end{tabular}

Robust standard errors in parentheses

$* * * \mathrm{p}<0.001,{ }^{* *} \mathrm{p}<0.01, * \mathrm{p}<0.05$ 
Table 3: Fixed-effects models predicting satisfaction with job

\begin{tabular}{|c|c|c|c|c|}
\hline & $\begin{array}{l}\text { Aspirations- } \\
\text { Attainment }\end{array}$ & $\begin{array}{c}\text { Parent } \\
\text { comparison }\end{array}$ & $\begin{array}{c}\text { Sibling } \\
\text { comparison }\end{array}$ & $\begin{array}{l}\text { Expected- } \\
\text { Achieved }\end{array}$ \\
\hline \multicolumn{5}{|l|}{ Aspiration-attainment match } \\
\hline Short of aspiration & $\begin{array}{c}-0.066^{*} \\
(0.03)\end{array}$ & & & \\
\hline Exceeded aspirations & $\begin{array}{l}-0.024 \\
(0.03)\end{array}$ & & & \\
\hline \multicolumn{5}{|l|}{ Parent-respondent match } \\
\hline Short of parental attainment & & $\begin{array}{l}-0.029 \\
(0.03)\end{array}$ & & \\
\hline Exceed parental attainment & & $\begin{array}{c}0.098^{* * *} \\
(0.03)\end{array}$ & & \\
\hline \multicolumn{5}{|l|}{ Sibling-respondent match } \\
\hline Short of sibling attainment & & & $\begin{array}{l}0.047 \\
(0.03)\end{array}$ & \\
\hline Exceed sibling attainment & & & $\begin{array}{l}0.034 \\
(0.03)\end{array}$ & \\
\hline \multicolumn{5}{|c|}{ Expected attainment-attainment match } \\
\hline Short of expected attainment & & & & $\begin{array}{c}-0.084^{* * * *} \\
(0.02)\end{array}$ \\
\hline Exceed expected attainment & & & & $\begin{array}{l}0.035 \\
(0.03)\end{array}$ \\
\hline Occupational SEI score & $\begin{array}{c}0.014 * * * \\
(0.00)\end{array}$ & $\begin{array}{c}0.012 * * * \\
(0.00)\end{array}$ & $\begin{array}{c}0.014 * * * \\
(0.00)\end{array}$ & $\begin{array}{c}0.012 * * * \\
(0.00)\end{array}$ \\
\hline Hourly wage & $\begin{array}{c}0.012 * * * \\
(0.00)\end{array}$ & $\begin{array}{c}0.011^{* * *} \\
(0.00)\end{array}$ & $\begin{array}{c}0.0112^{* * * *} \\
(0.00)\end{array}$ & $\begin{array}{c}0.012 * * * \\
(0.00)\end{array}$ \\
\hline Hours worked in survey week & $\begin{array}{c}0.005^{* * *} \\
(0.00)\end{array}$ & $\begin{array}{c}0.004 * * * \\
(0.00)\end{array}$ & $\begin{array}{c}0.005^{* * *} \\
(0.00)\end{array}$ & $\begin{array}{c}0.005 * * * \\
(0.00)\end{array}$ \\
\hline Health limitation & $\begin{array}{c}-0.145^{* * *} \\
(0.04)\end{array}$ & $\begin{array}{c}-0.155^{* * *} \\
(0.04)\end{array}$ & $\begin{array}{c}-0.149^{* * *} \\
(0.04)\end{array}$ & $\begin{array}{c}-0.141^{* * * *} \\
(0.03)\end{array}$ \\
\hline \multicolumn{5}{|l|}{ Marital status } \\
\hline Never married & $\begin{array}{l}0.041 \\
(0.02)\end{array}$ & $\begin{array}{c}0.045+ \\
(0.03)\end{array}$ & $\begin{array}{l}0.035 \\
(0.03)\end{array}$ & $\begin{array}{l}0.034 \\
(0.02)\end{array}$ \\
\hline Divorced/separated/widowed & $\begin{array}{l}0.011 \\
(0.02)\end{array}$ & $\begin{array}{l}0.028 \\
(0.03)\end{array}$ & $\begin{array}{l}0.009 \\
(0.02)\end{array}$ & $\begin{array}{l}0.023 \\
(0.02)\end{array}$ \\
\hline Has child & $\begin{array}{c}0.033^{* *} \\
(0.01)\end{array}$ & $\begin{array}{c}0.048^{* * *} \\
(0.01)\end{array}$ & $\begin{array}{c}0.045^{* * *} \\
(0.01)\end{array}$ & $\begin{array}{c}0.043 * * * \\
(0.01)\end{array}$ \\
\hline \multicolumn{5}{|l|}{ Employment status } \\
\hline Currently employed & $\begin{array}{c}0.114 * * * \\
(0.03)\end{array}$ & $\begin{array}{c}0.122 * * * \\
(0.04)\end{array}$ & $\begin{array}{c}0.127^{* * *} \\
(0.04)\end{array}$ & $\begin{array}{c}0.117 * * * \\
(0.03)\end{array}$ \\
\hline Out of the labor force & $\begin{array}{l}-0.066 \\
(0.04)\end{array}$ & $\begin{array}{l}-0.069 \\
(0.05)\end{array}$ & $\begin{array}{l}-0.056 \\
(0.05)\end{array}$ & $\begin{array}{l}-0.064 \\
(0.04)\end{array}$ \\
\hline Age & $\begin{array}{c}0.012 * * * \\
(0.00)\end{array}$ & $\begin{array}{c}0.010^{* * *} \\
(0.00)\end{array}$ & $\begin{array}{c}0.010^{* * *} \\
(0.00)\end{array}$ & $\begin{array}{c}0.012 * * * \\
(0.00)\end{array}$ \\
\hline
\end{tabular}


Observations

Number of ids

Standard errors in parentheses

*** $\mathrm{p}<0.001, * * \mathrm{p}<0.01, * \mathrm{p}<0.05$
124,732

9,302
116,151

5,125
126,962

9,684

\begin{tabular}{ccc}
114,795 & 116,151 & 126,962 \\
8,468 & 5,125 & 9,684 \\
\hline
\end{tabular}

